\title{
MAHASISWA DAN REVOLUSI INDUSTRI 4.0
}

\author{
Nova Jayanti Harahap \\ Sekolah Tinggi Ilmu Ekonomi (STIE) Labuhanbatu, Rantauprapat - Sumatera Utara
}

\begin{abstract}
The history of the industrial revolution starts from industry 1.0, 2.0, 3.0, to industry 4.0. The industrial phase is a real change of change. The industrial revolution is currently changing the phase where it is increasing its peak, with the advent of digital technology that has massive impacts on human life throughout the world. Through literature studies, this paper discusses qualitative data about the Industrial Revolution 4.0 discussing with students and their role in facing the Industrial Revolution 4.0. The results of this study show how in it is development, industrial revolution 4.0 brought human resources, especially for students. There are various challenges for the world of education, there are some that must be interesting to oppose negatively from Industrial Revolution 4.0 for students, improve the mastery of computer technology competencies, communication skills, the ability to support collaboratively, and the ability to learn and adapt to environmental changes.
\end{abstract}

Keywords: Industrial Revolution 4.0, Solution to Facing Industrial Revolution 4.0 for Students, Literature Study.

\section{ABSTRAK}

Sejarah revolusi industry dimulai dari industri 1.0, 2.0, 3.0, hingga industri 4.0. Fase industri merupakan real change dari perubahan yang ada. Revolusi industri saat ini memasuki fase keempat dimana sedang mengalami puncaknya, dengan lahirnya teknologi digital yang berdampak masif terhadap kehidupan manusia di seluruh dunia. Melalui studi literatur, tulisan ini bertujuan melihat dari pendekatan kualitatif data mengenai bagaimana kemunculan Industri 4.0 dikaitkan dengan mahasiswa serta perannya dalam menghadapi revolusi industry 4.0. Hasil studi ini menunjukkan bahwa dalam perkembangannya, revolusi industry 4.0 membawa pengaruh terhadap sumber daya manusia, terutama bagi mahasiswa. Muncul berbagai tantangan bagi dunia pendidikan, ada beberapa yang mesti diperhatikan untuk menghadapi dampak negative dari munculnya revolusi industry 4.0 bagi Mahasiswa, diantaranya peningkatan kompetensi penguasaan teknologi komputer, keterampilan berkomunikasi, kemampuan bekerjasama secara kolaboratif, dan kemampuan untuk terus belajar dan adaptif terhadap perubahan lingkungan. 


\section{Jurnal Ecobisma Vol 6 No. 1 Jan 2019}

Kata Kunci: Revolusi Industri 4.0, Solusi Menghadapi Revolusi Industri 4.0 Bagi Mahasiswa, Studi Literatur.

\section{A. PENDAhuluan}

Revolusi merupakan berubahnya corak sosial dan kebudayaan serta kebiasaan masyarakat umum yang menyangkut dasar atau pokok-pokok kehidupan masyarakat secara singkat. Industri adalah kegiatan ekonomi yang mengelola bahan mentah, bahan baku, menjadi barang berkualitas. 4.0 sendiri merupakan kode tren digitalisasi dan otomasi serta pertukaran data terkini dalam teknologi. Revolusi Industri 4.0 merupakan perubahan mendasar corak sosial masyarakat secara singkat dalam kegiatan ekonomi industri terkait segala sektor ekonomi industri.

Revolusi Industri 4.0 merupakan fase keempat dari proses revolusi industri. Revolusi Industri pertama terjadi di Inggris pada abad ke 18, ditandai dengan ditemukannya mesin uap yang mendominasi saat itu. Revolusi Industri kedua yang terjadi pada abad ke 19 ditandai dengan ditemukannya energi listrik dan Revolusi Industri ketiga pada tahun 1970 ditandai dengan pesatnya tekonologi sensor, interkoneksi dan analisis data yang akhirnya mengintegrasikan keseluruh teknologi industri. Hal ini lah yang mendorong terjadinya Revolusi Industri.

Prof Schawab menjelaskan, revolusi industri 4.0 telah mengubah hidup dan kerja manusia secara fundamental. Berbeda dengan revolusi industri sebelumnya, revolusi industri 4.0 ini memiliki skala, ruang lingkup dan kompleksitas yang lebih luas. Kemajuan teknologi baru yang mengintegrasikan dunia fisik, digital dan biologis telah mempengaruhi semua disiplin ilmu, ekonomi, industri dan pemerintah. Deskripsi di atas menggambarkan bahwa revolusi industri 4.0 akan merambah ke segala sendi ekonomi. Konsep digitalisasi ekonomi dominan menggunakan teknologi canggih dalam kegiatan ekonominya, akhirnya tenaga manusia yang notabene sebagai penyerap tenaga kerja menjadi terkesampingkan dan negara berkembang yang tidak mampu bersaing ekonominya akan memburuk akibat tingginya jumlah pengangguran.

Namun situasi revolusi industri 4.0 tidak dapat terhindarkan. Situasi saat inilah menuntut mahasiswa berperan aktif dalam menjaga stabilitas ekonomi terutama kelas menengah kebawah. Revolusi Industri 4.0 dalam dimensi peluang \& tantangannya. Revolusi industri saat ini memasuki fase keempat dimana sedang mengalami puncaknya, dengan lahirnya teknologi digital yang berdampak masif terhadap kehidupan manusia di seluruh dunia.

Karakteristik revolusi industri 4.0 ditandai dengan berbagai teknologi terapan, salah satu nya adalah sistem teknologi dan informasi yang mampu mengadopsi kemampuan manusia (artificial intelligence). Revolusi industri terkini mendorong sistem otomasi dalam semua proses aktivitas 
ekonomi. Perkembangan ilmu pengetahuan dan teknologi yang sangat pesat memberikan dampak yang besar terhadap kehidupan manusia. Teknologi internet yang semakin masif tidak hanya menghubungkan jutaan manusia di seluruh dunia tetapi juga telah menjadi basis bagi transaksi perdagangan dan transportasi secara online.

Munculnya bisnis transportasi online seperti Gojek, Uber dan Grab menunjukkan integrasi aktivitas manusia dengan teknologi informasi dan ekonomi menjadi semakin meningkat. Revolusi Industri 4.0 tidak hanya menyediakan peluang, tetapi juga tantangan bagi generasi milineal. Karena, dalam situasi ini banyak peluang -- peluang dari canggihnya teknologi yang dapat mempermudah akses dalam segala sektor kehidupan. Layanan menjadi lebih cepat dan efisien serta memiliki jangkauan koneksi yang lebih luas dengan sistem online Banyak kemudahan dan inovasi yang diperoleh dengan adanya dukungan teknologi digital.

Namun, juga menjadi tantangan ditengah masyarakat yang tidak dapat menyeimbangkan dengan pesatnya perkembangan teknologi saat ini digitalisasi program juga membawa dampak negatif. Peran manusia setahap demi setahap diambil alih oleh mesin otomatis. Akibatnya, jumlah pengangguran dan kemiskinan semakin meningkat. Beberapa bidang pekerjaan yang dapat mendukung berkembangnya revolusi industry 4.0 diantaranya yang berkaitan dengan keahlian Komputer, Matematika, Arsitektur dan Teknik akan semakin banyak dibutuhkan. Bidang-bidang keahlian ini diproyeksikan sesuai dengan tuntutan pekerjaan yang mengandalkan teknologi digital.

\section{B. Pembahasan}

\section{Revolusi Industri}

\section{Sejarah Revolusi Industri}

Konsep revolusi industri 4.0 ini merupakan konsep yang pertama kali diperkenalkan oleh Profesor Klaus Schwab. Beliau merupakan ekonom terkenal asal Jerman sekaligus penggagas World Economic Forum(WEF) yang melalui bukunya, The Fourth Industrial Revolution, menyatakan bahwa revolusi industri 4.0 secara fundamental dapat mengubah cara kita hidup, bekerja, dan berhubungan satu dengan yang lain.

Dalam presentasinya, salah satu dosen Institut Teknologi Bandung (ITB), Richard Mengko, yang mengutip dari A.T. Kearney, mengungkap sejarah revolusi industri sampai akhirnya menyentuh generasi ke-4 ini. Berikut ini empat tahap evolusi industri dari dahulu hingga kini. 


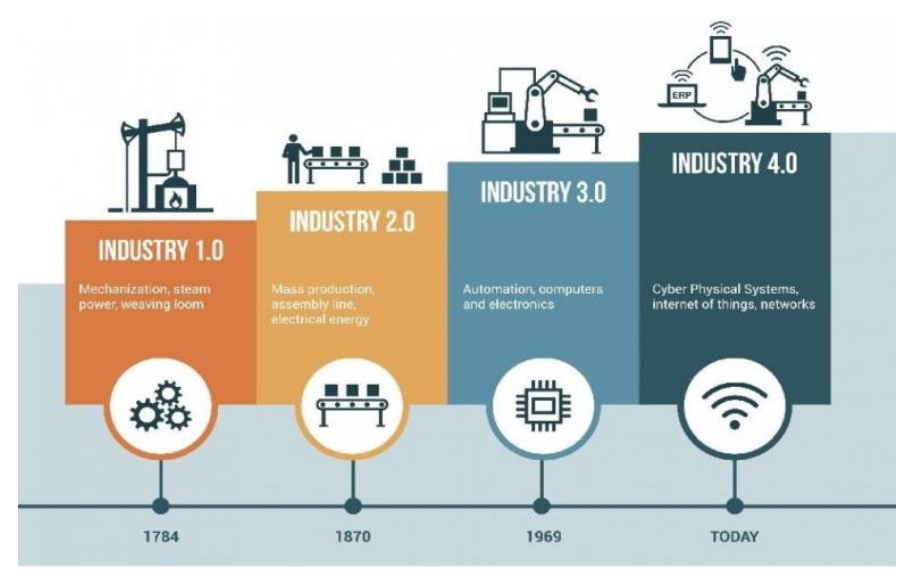

1. Revolusi industri yang pertama terjadi pada akhir abad ke-18. Hal ini ditandai dengan ditemukannya alat tenun mekanis pertama pada tahun 1784. Kala itu, industri diperkenalkan dengan fasilitas produksi mekanis yang menggunakan tenaga air dan uap. Peralatan kerja yang awalnya bergantung pada tenaga manusia dan hewan akhirnya digantikan dengan mesin tersebut. Akibatnya, meski jumlah produksi meningkat, banyak orang yang menganggur.

2. Revolusi industri 2.0 terjadi di awal abad ke-20.Kala itu ada pengenalan produksi massal berdasarkan pembagian kerja. Produksi massal ini dimungkinkan dengan adanya listrik dan jalur perakitan. Lini produksi pertama melibatkan rumah potong hewan di Cincinnati, Amerika Serikat, pada 1870.

3. Awal tahun 1970 ditengarai sebagai perdana kemunculan revolusi industri 3.0 yang dimulai dengan penggunaan elektronik dan teknologi informasi guna otomatisasi produksi. Debut revolusi industri generasi ketiga ditandai dengan kemunculan pengontrol logika terprogram pertama (PLC), yakni modem 084-969. Sistem otomatisasi berbasis komputer ini membuat mesin industri tidak lagi dikendalikan manusia. Biaya produksi dapat ditekan oleh karena penerapan hal ini.

4. Awal 2018 hingga sekarang, zaman revolusi industri 4.0. adalah industri yang menggabungkan teknologi otomatisasi dengan teknologi cyber. Ini merupakan tren otomatisasi dan pertukaran data dalam teknologi manufaktur. Pada era ini, industri mulai menyentuh dunia virtual, berbentuk konektivitas manusia, mesin dan data, semua sudah ada di mana-mana. Istilah ini dikenal dengan nama Internet of Things (IoT).

\section{Hubungan Revolusi Industri dengan Mahasiswa}

Dengan memasuki revolusi industri 4.0, persaingan akan berada di level yang berbeda dari sebelumnya. Sebagai pemuda Indonesia, adalah tanggung jawab untuk berkontribusi sebaik 
mungkin. Karena tidak ada orang lain yang akan membela ekonomi Indonesia Tidak ada orang lain yang akan menikmati manfaat dari pertumbuhan ekonomi.

Mahasiswa dalam kiprahnya menjadi instrumen penting dalam mengamalkan Tri Dharma Perguruan tinggi, yaitu sebagai pendidik dan pengajar, Penelitian dan pengembangan serta pengabdian masyarakat. Sebagai pengajar dan pendidik, mahasiswa di tuntut mampu berperan dalam mempersiapkan kualitas Sumber Daya Manusia Indonesia dengan memberikan pendidikan serta pendampingan kepada masyarakat agar mampu bersaing secara kreatifitas dan kemandirian ekonomi dengan melakukan kegiatan kemahasiswaan yang berposdayakan masyarakat ekonomi menengah kebawah.

Dalam hal penelitian dan pengembangan, mahasiswa memiliki tanggung jawab menemukan peluang masyarakat menengah kebawah dalam mengembangkan ekonominya di Era Revolusi Industri 4.0 dengan cara melakukan penelitian terkait solusi dalam meningkatkan ekonomi kerakyatan serta mengembangkan ide-ide pokok yang menguntungkan ekonomi kerakyatan. Sebagai Agent Of Change, Seorang mahasiswa di haruskan berperan aktif dalam hal pengabdian masyarakat, dengan turun langsug kelapangan dan merubah mindset konsumtif menjadi produktif dalam kegiatan ekonomi.

Pada akhirya, saat ini masyrakat membutuhkan peran mahasiswa guna menjaga stabilitas ekonomi menengah kebawah di era "serba mesin" ini. Mahasiswa harus kembali ke jati dirinya yang mampu menjadi Agent of Change, Agen Of Analisys dan Agen Of Cantrol supaya makasimal dalam mencapai cita-sita bangsa yaitu untuk memajukan kesejahteraan umum, mencerdaskan kehidupan bangsa serta memerdekakan rakyat Indonesia dari segala hal dalam kehidupan.

\section{Hubungan Revolusi Industri dengan Pendidikan}

Untuk menghadapi era revolusi industri 4.0, diperlukan pendidikan yang dapat membentuk generasi kreatif, inovatif, serta kompetitif. Hal tersebut salah satunya dapat dicapai dengan cara mengoptimalisasi penggunaan teknologi sebagai alat bantu pendidikan yang diharapkan mampu menghasilkan output yang dapat mengikuti atau mengubah zaman menjadi lebih baik. Indonesia pun perlu meningkatkan kualitas lulusan sesuai dunia kerja dan tuntutan teknologi digital.

Sudah saatnya kita meninggalkan proses pembelajaran yang cenderung mengutamakan hapalan atau sekadar menemukan satu jawaban benar dari soal. Metode pembelajaran pendidikan Indonesia harus mulai beralih menjadi proses-proses pemikiran yang visioner, termasuk mengasah kemampuan cara berpikir kreatif dan inovatif. Hal ini diperlukan untuk menghadapi berbagai perkembangan teknologi dan ilmu pengetahuan. 
Pengembangan kecerdasan buatan atau Artificial Intelligence (AI) bergerak semakin cepat dan mengalami kemajuan pesat dalam setiap bidang kehidupan manusia. Mulai dari perawatan kesehatan, kontrol iklim dan hasil panen, hingga pendidikan. Penggabungan AI dengan kecerdasan alami mansusia membuat potensi individu bisa menjadi lebih maksimal dan memungkinkan pencapaian yang lebih besar.

Untuk mengembangkan dan menyebarkan solusi yang didukung oleh AI, diperlukan penerapan 6 prinsip utama. 6 prinsip tersebut adalah:

\section{Privasi dan keamanan.}

Sama seperti teknologi lainnya, sistem AI harus mematahui UU privasi yang mengatur mengenai pengumpulan, penggunaan, dan penyimpanan data. Sistem AI juga harus memastikan informasi pribadi yang digunakan sesuai dengan standar privasi dan dilindungi dari pencurian dan penyalahgunaan.

\section{Transparansi.}

Mengingat AI semakin memengaruhi kehidupan setiap orang, informasi kontekstual mengenai bagaimana sistem AI beroperasi harus diberikan. Hal ini untuk membuat masyarakat paham mengenai bagaimana keputusan dibuat dan lebih mudah dalam mengidentifikasi potensi bias, kesalahan, dan hasil-hasil yang tidak diinginkan.

\section{Keadilan.}

Saat sistem AI membuat keputusan mengenai perawatan medis atau pekerjaan, sistem tersebut harus membuat rekomendasi yang sama bagi semua orang dengan kualifikasi dan gejala yang serupa.

\section{Keandalan}

Sistem AI harus dirancang agar dapat beroperasi dalam parameter yang jelas dan menjalani pengujian yang ketat untuk memastikan sistem tersebut merespons dengan aman dalam situasi yang tidak terprediksi. Sistem AI juga tidak boleh berevolusi dengan cara yang tidak sesuai dengan ekspektasi.

\section{Inklusivitas}

Masyarakat harus memegang peran dalam dalam membuat keputusan mengenai bagaimana dan kapan sistem AI harus dimanfaatkan.

\section{Akuntabilitas}

Orang yang mendesain serta memasang sistem AI haruslah bertanggung jawab mengenai bagaimana sistem tersebut akan beroperasi.

Enam hal tersebut perlu diperhatikan untuk mengubah Indonesia menjadi negara yang kompetitif namun tetap didasarkan pada kepercayaan dan panduan etika. 


\section{Dampak Revolusi Industri}

Revolusi industri generasi empat tidak hanya menyediakan peluang, tetapi juga tantangan bagi generasi milineal. Kemajuan ilmu pengetahuan dan teknologi sebagai pemicu revolusi indutri juga diikuti dengan implikasi lain seperti pengangguran, kompetisi manusia vs mesin, dan tuntutan kompetensi yang semakin tinggi.

Menurut Prof Dwikorita Karnawati (2017), revolusi industri 4.0 dalam lima tahun mendatang akan menghapus 35 persen jenis pekerjaan. Dan bahkan pada 10 tahun yang akan datang jenis pekerjaan yang akan hilang bertambah menjadi 75 persen. Hal ini disebabkan pekerjaan yang diperankan oleh manusia setahap demi setahap digantikan dengan teknologi digitalisasi program. Dampaknya, proses produksi menjadi lebih cepat dikerjakan dan lebih mudah didistribusikan secara masif dengan keterlibatan manusia yang minim. Di Amerika Serikat, misalnya, dengan berkembangnya sistem online perbankan telah memudahkan proses transaksi layanan perbankan. Akibatnya, 48.000 teller bank harus menghadapi pemutusan hubungan kerja karena alasan efisiensi.

Bahkan menurut survey McKinsey, sebuah korporasi konsultan manajemen multinasional, di Indonesia sebanyak 52,6 juta lapangan pekerjaan berpotensi digantikan dengan sistem digital. Dengan kata lain, 52 persen angkatan kerja atau merepresentasikan 52,6 juta orang akan kehilangan pekerjaan.

\section{KESIMPULAN}

Revolusi industri saat ini memasuki fase keempat. Perkembangan ilmu pengetahuan dan teknologi yang sangat pesat memberikan dampak yang besar terhadap kehidupan manusia. Banyak kemudahan dan inovasi yang diperoleh dengan adanya dukungan teknologi digital. Layanan menjadi lebih cepat dan efisien serta memiliki jangkauan koneksi yang lebih luas dengan sistem online. Hidup menjadi lebih mudah dan murah.

Namun demikian, digitalisasi program juga membawa dampak negatif. Peran manusia setahap demi setahap diambil alih oleh mesin otomatis. Akibatnya, jumlah pengangguran semakin meningkat. Hal ini tentu saja akan menambah beban masalah lokal maupun nasional. Oleh karena itu, untuk memanfaatkan peluang dan menjawab tantangan revolusi industri 4.0, para mahasiswa dan alumni Universitas Terbuka wajib memiliki kemampuan literasi data, teknologi dan manusia (Sumber: http://belmawa.ristekdikti.go.id/2018/01/17/era-revolusiindustri-4-0-perlu-persiapkan-literasi-data-teknologi-dan-sumber-daya-manusia/).

Literasi data dibutuhkan oleh mahasiswa untuk meningkatkan skill dalam mengolah dan menganalisis big data untuk kepentingan peningkatan layanan publik dan bisnis. Literasi 
teknologi menunjukkan kemampuan untuk memanfaatkan teknologi digital guna mengolah data dan informasi. Sedangkan literasi manusia wajib dikuasai karena menunjukan elemen softskill atau pengembangan karakter individu untuk bisa berkolaborasi, adaptif dan menjadi arif di era "banjir" informasi.

\section{REKOMENDASI}

Revolusi industri 4.0 salah satu kelemahan atau tantangan terbesarnya adalah banyak tenaga kerja yang tidak kompatibel. Dimana terpaut pada suatu titik kondisi tenaga kerja yang tidak terlatih. Indonesia memiliki angkatan kerja terbesar ke-4 di dunia, namun sangat kekurangan talenta. Anggaran pendidikan pemerintah saat ini hanya sekitar US\$114/kapita.

Tantangan ini perlu dijawab dengan peningkatan kompetensi terutama penguasaan teknologi komputer, keterampilan berkomunikasi, kemampuan bekerjasama secara kolaboratif, dan kemampuan untuk terus belajar dan adaptif terhadap perubahan lingkungan. Disinilah peran mahasiswa yang tidak hanya sebagai penikmat dari kemudahan akses di era modern ini tetapi, bagaimana mahasiswa menyikapi sebuah revolusi industri. Mahasiswa dapat memperoleh manfaat dari digitalisasi ekonomi saat ini, tetapi hanya jika kita mempersiapkan diri dengan cukup baik. Untuk mengantisipasi revolusi industri 4.0, penting untuk: Meningkatkan daya saing sumber daya manusia, kita tidak lagi berkompetisi dengan sesama orang Indonesia saja tetapi juga bersaing dengan talenta asing lainnya. Ini adalah tanggung jawab sebagai generasi penerus Indonesia untuk melengkapi diri dengan bakat kompetitif melalui program pendidikan yang kompetitif.

Memelihara kewirausahaan di Indonesia, Ini terbukti selama krisis yang terjadi beberapa tahun lalu. Sektor pengusaha Indonesia yang diisi oleh aktivitas produktif dapat mempertahankan stabilitas ekonomi. Di atas itu, itu juga akan membuka peluang kerja untuk bakat lokal. Mendorong reformasi dalam birokrasi, Ini sangat penting karena pada akhirnya akan meningkatkan perbaikan sosial \& ekonomi. Ini juga merupakan gerakan yang diperlukan untuk menciptakan fondasi kokoh stabilitas ekonomi yang dihadapi perdagangan bebas dan MEA.

\section{DAFTAR PUSTAKA}

Afwan, M. (2013). Leadership on technical and vocational education in community college

[Versi elektronik]. Journal of Education and Practice, 4 (21), 21-23. 


\section{Jurnal Ecobisma Vol 6 No. 1 Jan 2019}

Bukit, M. (2014). Strategi dan inovasi pendidikan kejuruan dari kompetensi ke kompetisi. Bandung: Alfabeta.

Irianto, D. (2017). Industry 4.0; The Challenges of Tomorrow. Disampaikan pada Seminar Nasional Teknik Industri, Batu-Malang.

Era Industri 4.0: Tantangan dan Peluang Perkembangan Pendidikan Kejuruan Indonesia

Kuncoro, Ari.(2019). Revolusi Industri 4.0 dan Dampaknya Terhadap Perekonomian Indonesia. Jakarta. http://www.feb.ui.ac.id/blog/2019/01/12/ari-kuncoro-revolusi-industri-4-0-dandampaknya-terhadap-perekonomian-indonesia/ diakses Februari 2019

Kuswana, W.S. (2013). Filsafat teknologi, vokasi dan kejuruan. Bandung: Alfabeta Bandung.

Schawab (2016). Industry 4.0: the challenges of the transforming manufacturing. Germany: BPIFrance.

Liffler, M., \& Tschiesner, A. (2013). The Internet of Things and the Future of Manufacturing. McKinsey \& Company.

Karnawati, Dwikorita (2017). revolusi industri 4.0. http://marketeers.com/mengenal-marketing4-0-dalam-konteks-ekonomi-digital/ diakses Januari 2019 